\title{
YOGHURT WITH GOJI BERRY FRUITS (LICIUM BARBARUM L.)
}

\author{
Ira Taneva, Tsvetan Valev \\ Faculty of Technics and Technologies of Yambol, \\ Trakia University of Stara Zagora, Bulgaria \\ 38 Graf Ignatiev str., 8602, Yambol, Bulgaria \\ e-mail: ira_64@abv.bg
}

\begin{abstract}
A yoghurt was obtained with the addition of goji berry (Lycium barbarum L.) fruits. The sequence of technological operations has been established. The active acidity of the yoghurt samples was determined during coagulation and in the storage period for 20 days $(1,10$ and 20 days). During storage, $\mathrm{pH}$ and syneresis decreases. As a result of organoleptic assessments, yogurt with a $4 \%$ addition of goji berry fruits is preferred after a control sample. The study shows that goji berries can be used in the production of yoghurt as a functional nutritional ingredient.
\end{abstract}

Keywords: fruit yogurt, goji berry, fermentation.

\section{INTRODUCTION}

Fermented dairy products such as yoghurt are important for people's health, because the probiotics necessary for the human organism are being obtained. The most well-known probiotics are lactic acid bacteria and bifidobacteria used in the production of yoghurt and other dairy products $[9,14,16]$.

The production of yoghurt with various nutritional supplements (nuts, hazelnuts, sesame and flaxseed extract, blueberries and aronia juice, etc.) increases its biological completeness. Recent studies have shown interest in fermented dairy products further enriched with bioactive compounds [2, 15].

The rich chemical composition of Lycium barbarum L. allows them to be used as an additive in the production of yoghurt. Fruit berries are rich in: protein $-55,4 \mathrm{~g} / \mathrm{kg}$; fat $-10,4 \mathrm{~g} / \mathrm{kg}$; carbohydrates - 267,6 $\mathrm{g} / \mathrm{kg}$ fiber - 37,4 g/kg; mineral substances - 13,8 $\mathrm{g} / \mathrm{kg}$ [11].

Rotar A. et al. [13] have proven that adding berries to fermented milk increases the viability of probiotic bacteria during storage.

The purpose of this study is to track the changes in active acidity during coagulation and storage as well as the process of yoghurt syneresis with the addition of goji berries.

\section{MATERIAL AND METHODS}

For the purposes of the experiment, yogurt is obtained from raw cow's milk obtained from the region of Yambol, Bulgaria with a fat content of $3,4 \%$; protein content $-3,2 \%$; dry non-fat residue $-9,1 \%$; density $-1,029 \mathrm{~g} / \mathrm{cm}^{3}$.

The lyophilized starter culture (Lactobacillus delbreukii ssp bulgaricus and Streptococcus thermophilus) for direct inoculation of Lactina Ltd., Bulgaria with lactic acid bacteria of more than $9,5.10^{9}$ CFU.g ${ }^{-1}$ was used for the starter culture.

Dry goji berries commercially available were used. 


\section{ART'TE

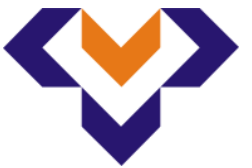 \\ Ipplied Researrohes in Technics, Technologies and Education \\ Journal of the Faculty of Technics and Technologies, Trakia University \\ https://sites.google.com/a/trakia-uni.bg/artte/}

After grading, receiving and filtering the raw milk, it is pasteurized at a temperature of $92 \div 95{ }^{\circ} \mathrm{C}$ for 20 minutes. The pasteurized milk is cooled to a temperature of $45{ }^{\circ} \mathrm{C}$ and decanted with a lyophilized starter culture (Lactobacillus delbreukii ssp bulgaricus, Streptococcus thermophilus). The inoculated milk is thermostated at a temperature of $42 \div 45{ }^{\circ} \mathrm{C}$ for $3 \div 3,5 \mathrm{~h}$. At $\mathrm{pH} 4,8 \div 4,9$, the coagulated milk is homogenized (stirring), quickly cooled to $18 \div 20{ }^{\circ} \mathrm{C}$ and to it is added dry fruits of gherkins in quantities $2 \%(\mathrm{~S} 1), 4 \%$ (S2) and $6 \%$ (S3), based on the weight of the milk. Before the addition, the fruits are pre-washed and dried and ground to size $4 \div 6 \mathrm{~mm}$. The resulting yoghurt is stored at $0 \div 4{ }^{\circ} \mathrm{C}$. for further analysis. The same technology was obtained yoghurt without the addition of fruit sample (S0).

\subsection{Physical analyses}

The active acidity $(\mathrm{pH})$ of the samples was measured using a $\mathrm{pH}$ meter (Model MS 2011, Microsyst, Plovdiv, Bulgaria) equipped with an electrode ( $\mathrm{pH}$ electrode Sensorex, Garden Grove, CA, USA); The titratable acidity $\left({ }^{\circ} \mathrm{T}\right)$ of the samples was determined by the Thorner method BNS 1111-80 [3].

For the determination of the syneresis, the method indicated by Todorov et al. [7].

\subsection{Microbiological analyses}

The total amount of lactic acid bacteria (Lactobacillus bulgaricus and Streptococcus thermophiles): Sample preparation was performed according to IDF standard 122C: 1996. The appropriate dilutions were inoculated into selective M17 and MRS agar as described in IDF Standard 117B: 1997 [8].

\subsection{Organoleptic evaluation of fermented milk}

The criteria for organoleptic evaluation measure the following: taste and smell - 40 points, texture - 20 points, appearance - 20 points, color - 20 points (maximum total score - 100 points) according to BNS 15612-83 [4].

The attempts are made with three reps. All data obtained were processed at a level of significance $\alpha=0,05$.

\section{RESULTS AND DISCUSSION}

Figure 1 shows the change in titratable acidity values up to 72 hours from coagulation of yogurt. The data are compared with those obtained for yoghurt without fruit supplementation (control).

It can be seen that as the coagulation process progresses, the titratable acidity of both the control and the work samples increases gradually. In the fourth hour of coagulation the highest value of the titratable acidity was observed. S3 sample was 86 oT. At the control (S0) the titratable acidity for the same time was $82 \mathrm{oT}$, the difference being negligible. These results correlate with the results of Balabanova T., et al. [1] and Bueno L., et al. [5]. 


\section{IRTTIE Y}

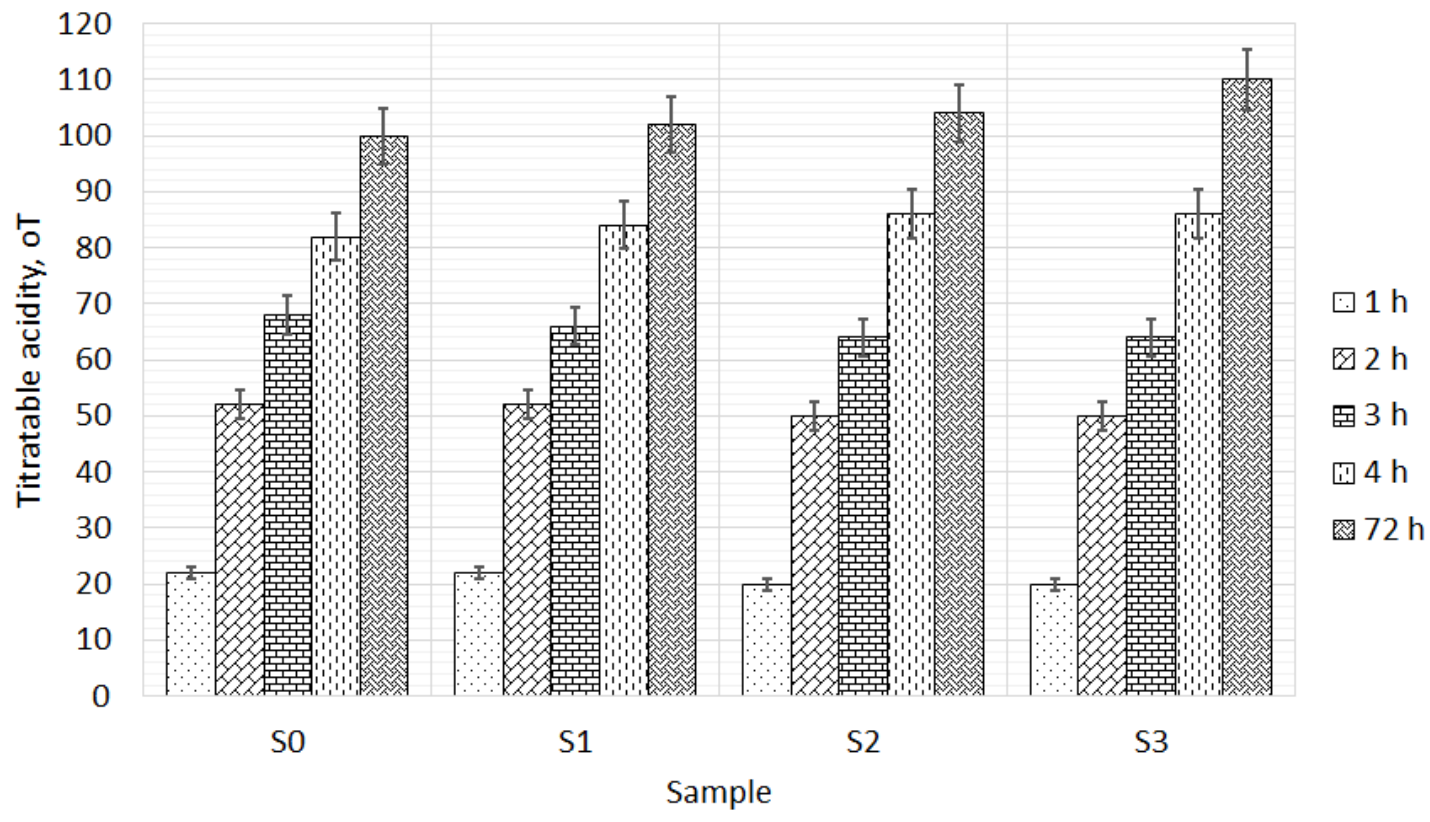

Figure 1.

Change of titratable acidity

Figure 2 shows the active acidity of the yoghurt obtained during the storage period up to 20 days.

During storage there is a constant tendency towards a gradual increase in acidity. Active acidity ranges from 4.8 on the first day to 4.1 on the 20 th day of storage.

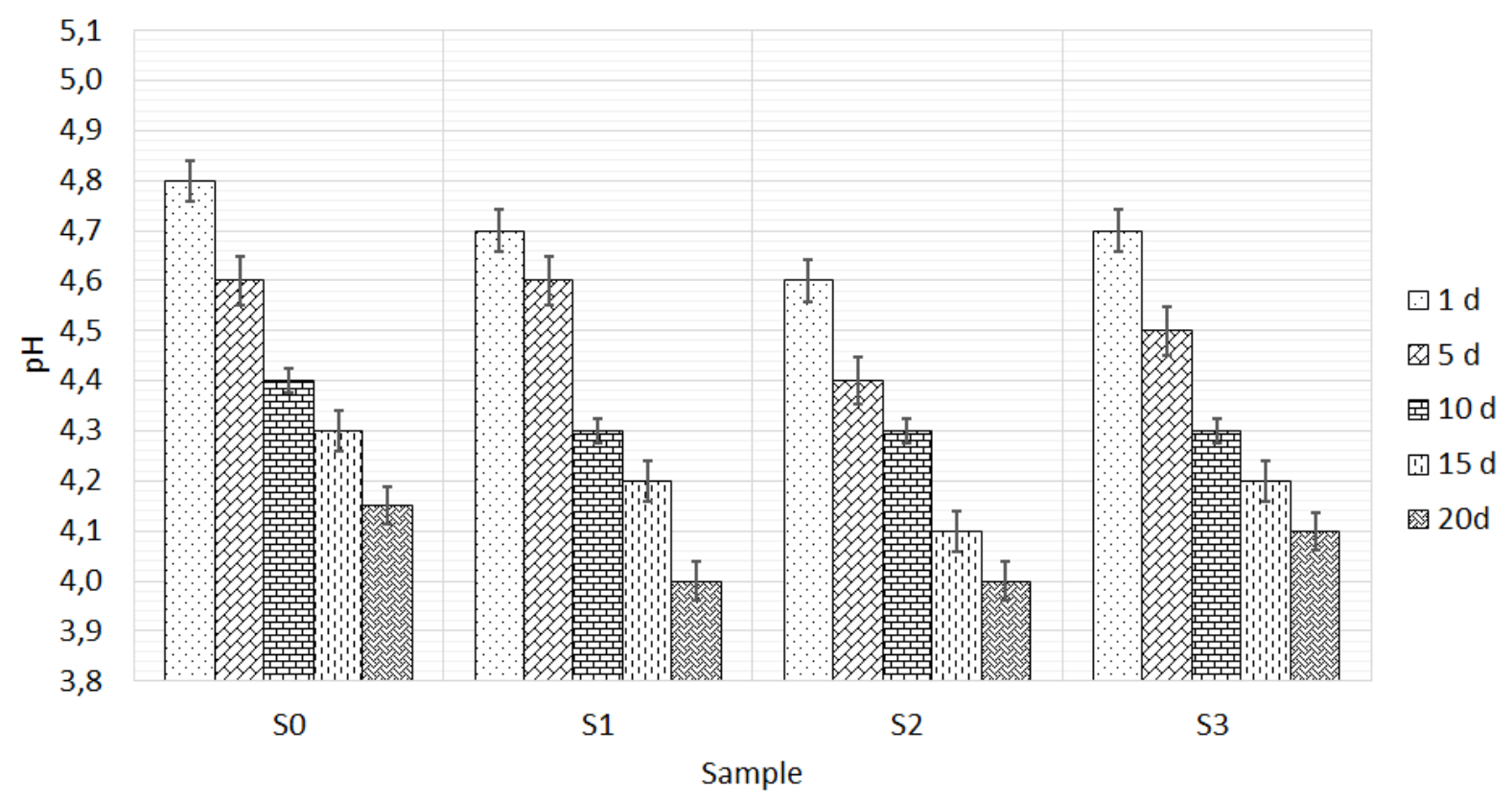

Figure 2.

Change of active acidity

IRTIIE Vol. 7, No. 2, 2019 ISSN 1314-8788 (print), ISSN 1314-8796 (online), doi: 10.15547/artte.2019.02.007 
The slight change in the active acidity is explained by the buffer capacity of the milk.

From the titratable and active acidity data of the tested milk, it can be concluded that the addition of 2, 4 and $6 \%$ of berries does not affect the dynamics of acidification and the proper flow of lactic acid fermentation.

The amount of milk produced is determined by the amount of serum, which is released in five hours. Separated whale is one of the yogurt quality criteria, and the lower it is, the better. The results for the quantity of beads are presented in Table 1.

Table 1. Yogurt syneresis with added berry berries

\begin{tabular}{|c|c|c|c|c|c|}
\hline \multirow{2}{*}{ № } & $\begin{array}{c}\text { Duration, } \\
\text { min }\end{array}$ & Control & $\mathrm{S} 1$ & $\mathrm{~S} 2$ & $\mathrm{~S} 3$ \\
\cline { 3 - 6 } & 5 & serum, $\mathrm{cm}^{3}$ & serum, $\mathrm{cm}^{3}$ & Serum, $\mathrm{cm}^{3}$ & serum, $\mathrm{cm}^{3}$ \\
\hline 1 & 10 & $10,0 \pm 1,3$ & $5,0 \pm 0,8$ & $3,0 \pm 0,4$ & $1,0 \pm 0,1$ \\
\hline 2 & 15 & $15,0 \pm 2,2$ & $6,0 \pm 0,7$ & $3,5 \pm 0,9$ & $1,2 \pm 0,1$ \\
\hline 3 & 30 & $19,0 \pm 4,2$ & $8,0 \pm 1,1$ & $4,0 \pm 0,5$ & $1,5 \pm 0,1$ \\
\hline 4 & 62 & $22,0 \pm 3,2$ & $9,0 \pm 3,2$ & $4,5 \pm 0,2$ & $1,8 \pm 0,1$ \\
\hline 5 & $24,0 \pm 5,1$ & $10,0 \pm 3,1$ & $5,0 \pm 1,1$ & $2,0 \pm 0,2$ \\
\hline 6 & 120 & $35,0 \pm 6,2$ & $11,0 \pm 4,7$ & $5,2 \pm 1,1$ & $2,2 \pm 0,1$ \\
\hline 7 & 180 & $42,0 \pm 4,2$ & $12,0 \pm 1,1$ & $5,5 \pm 2,4$ & $2,5 \pm 0,7$ \\
\hline 8 & 240 & $45,0 \pm 5,3$ & $12,0 \pm 2,4$ & $6,0 \pm 1,7$ & $2,8 \pm 0,2$ \\
\hline 9 & 300 & $47,0 \pm 7,7$ & $13,0 \pm 1,8$ & $6,5 \pm 1,3$ & $3,5 \pm 0,5$ \\
\hline
\end{tabular}

It is evident that in the control, the syneresis is the highest $\left(47 \mathrm{~cm}^{3}\right)$, whereas in the samples with the addition of goji berries it decreases. For yogurt supplemented with $6 \%$ fruit of goji berry (sample S3) for five hours, the amount of whey is $3,5 \mathrm{~cm}^{3}$. It is obvious that the fruit absorbs part of the water and thus reduces the water phase in the milk, improving its consistency.

The total number of lactic acid bacteria in the yoghurt obtained was monitored as shown in Table 2.

Table 2. Number of lactic acid bacteria in yoghurt during the storage period

\begin{tabular}{|c|l|l|c|c|c|}
\hline \multirow{2}{*}{$\begin{array}{c}\text { Duration of } \\
\text { storage, day }\end{array}$} & \multirow{2}{*}{ Bacteria } & \multicolumn{4}{|c|}{ CFU. g- } \\
\cline { 2 - 6 } & & Control & S1 & S2 & S3 \\
\hline \multirow{2}{*}{ Day 1} & S. termophillus & $1,4.10^{\prime}$ & $1,6.10^{\prime}$ & $1,5.10^{\prime}$ & $1,5.10^{\prime}$ \\
\cline { 2 - 6 } & Lactobacillus & $1,6.10^{7}$ & $1,9.10^{7}$ & $1,8.10^{7}$ & $1,6.10^{7}$ \\
\hline \multirow{2}{*}{ Day 10} & S. termophillus & $1,6.10^{\prime}$ & $1,9.10^{\prime}$ & $1,8.10^{\prime}$ & $1,7.10^{\prime}$ \\
\cline { 2 - 6 } & Lactobacillus & $2,3.10^{8}$ & $2,6.10^{8}$ & $2,5.10^{8}$ & $2,2.10^{8}$ \\
\hline \multirow{2}{*}{ Day 20 } & S. termophillus & $1,5.10^{6}$ & $1,8.10^{6}$ & $1,7.10^{5}$ & $1,6.10^{5}$ \\
\cline { 2 - 6 } & Lactobacillus & $1,3.10^{6}$ & $1,7.10^{\prime}$ & $1,6.10^{6}$ & $1,5.10^{6}$ \\
\hline
\end{tabular}

The addition of goji berries in samples S2 and S3 during their storage leads to a reduction of S. Termophillus due to its sensitivity to lactic acid. One of the most important properties of lactic acid bacteria is their ability to degrade lactose. Exhaustion of the quantity during the storage period also reduces their number in the obtained milk. On the 20th day of storage, it was $1,3 \cdot 10^{6}$ at the control and $1,7.10^{7}$ at $\mathrm{S} 1$. The production of lactic acid from Lactobacillus

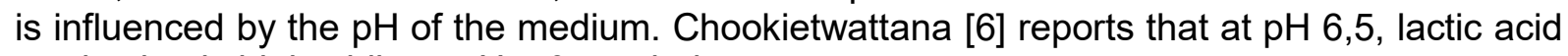
production is high while at $\mathrm{pH} 5,0 \div 5,5$ it decreases

Similar results for lactic acid bacteria reported by Michael et al. [10]. Rotar et al. [12] report a significant reduction in viable lactic acid bacteria to $10^{3} \mathrm{CFU} / \mathrm{g}$ at the end of the storage period in yogurt without additives. 


\section{ARITIE

Organoleptic evaluation was performed on days 1 and 20 of storage of the resulting yoghurt at $1 \pm 4{ }^{\circ} \mathrm{C}$ (Figures 3 and 4 ).

Deviations are observed in the organoleptic characteristics - appearance and taste of all samples, being the largest in the sample with 6\% added goji berries (S3). The assessors do not approve of the coloration of yogurt with more goji berries. Better evaluations were obtained by the control and sample S2 supplemented with $4 \%$ goji berries.

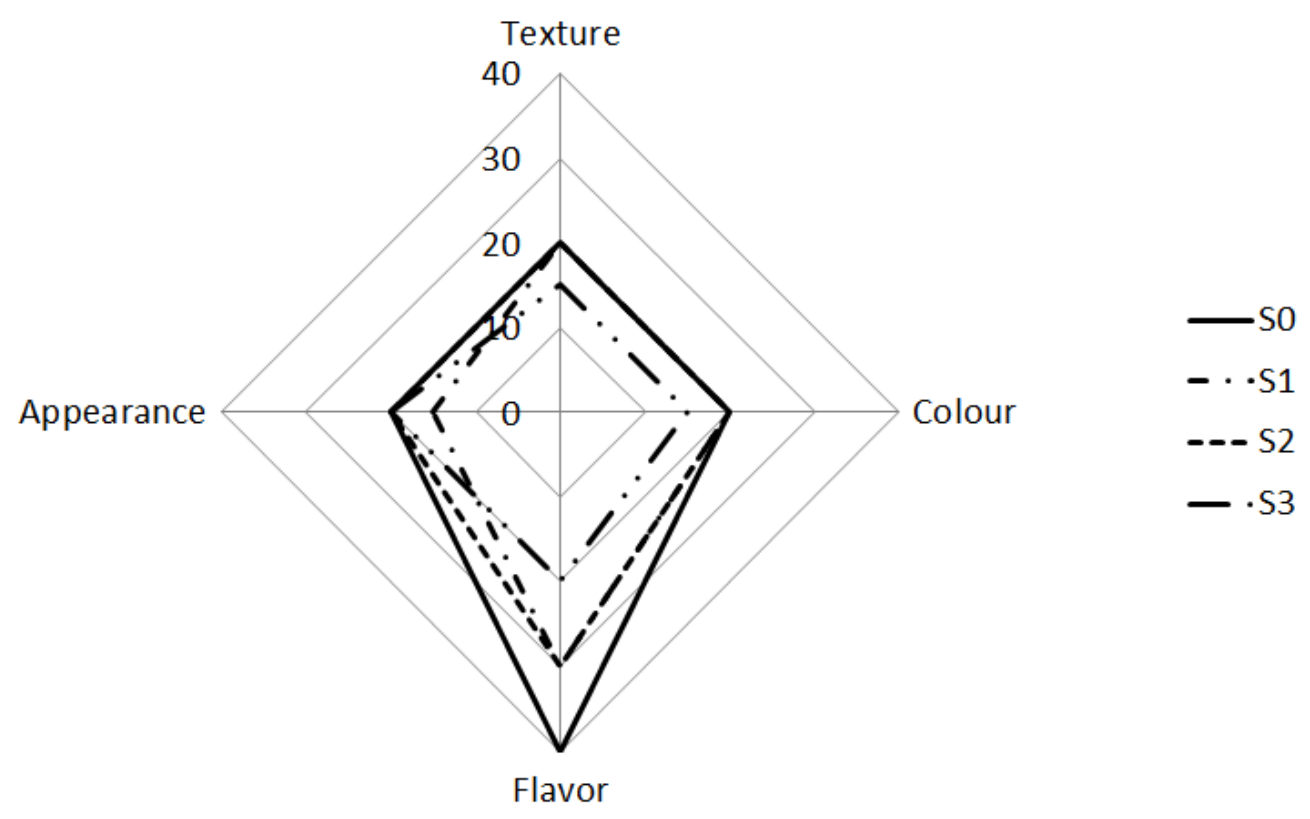

Figure 3. Organoleptic evaluation of samples on day 1 of storage

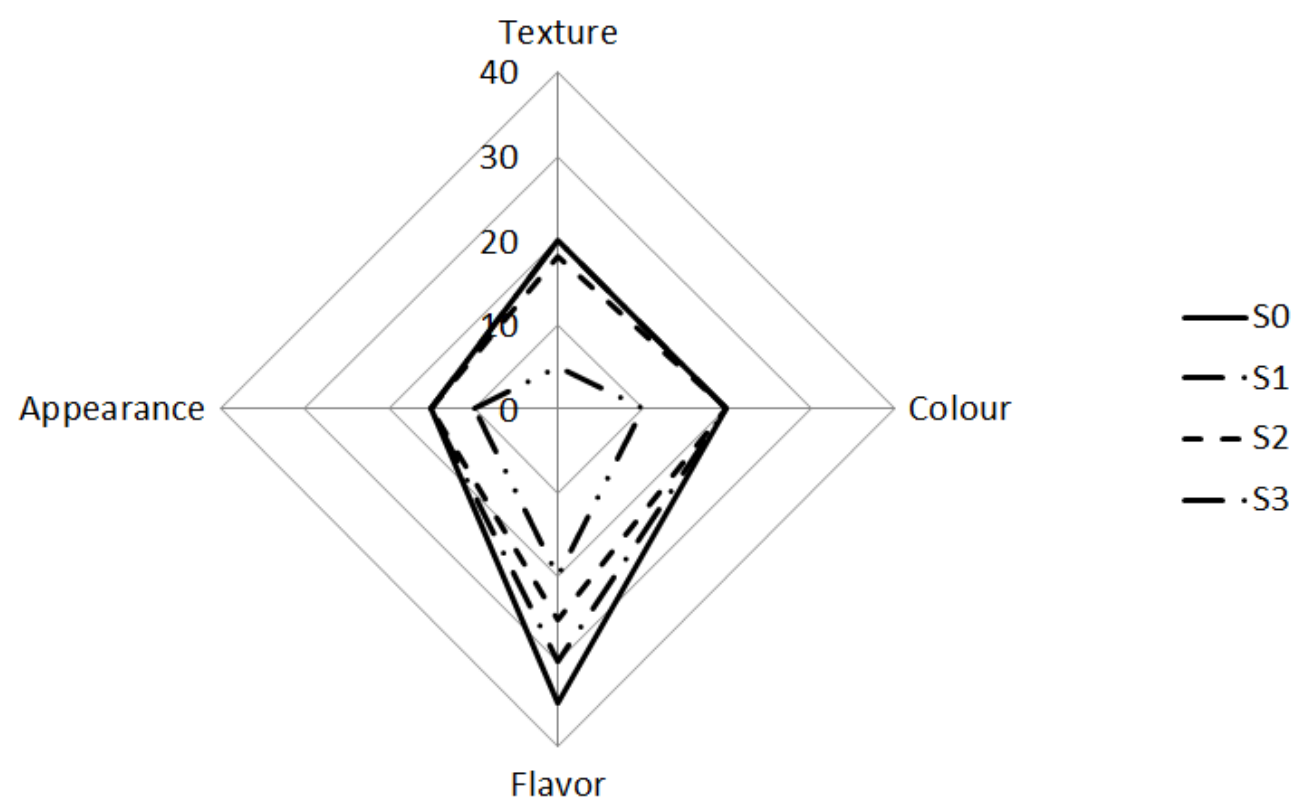

Figure 4. Organoleptic evaluation of samples on day 20 of storage 


\section{CONCLUSION}

The addition of goji berry fruits up to $4 \%$ improves the organoleptic characteristics of yogurt. During storage, good quality parameters of the resulting yoghurt are maintained. The addition of goji berry fruits improves the viability of lactic acid bacteria and maintains the prebiotic value of yogurt during storage. The results obtained in this study indicate that goji berries can be used as an enhancer of probiotic levels in yogurt.

Adding goji berries to yogurt gives the opportunity to expand the assortment of lactic acid products with prophylactic and medicinal properties on the human body.

\section{ACKNOWLEDGEMENTS}

The work is supported by scientific project 5.FTT/ 03.2019 „Possibilities of using bioprotectors in the production of functional foods".

\section{REFERENCES}

[1] Balabanova T., M. Ivanova, I. Ivanov, M. Dimitrova, M. Dushkova, R. Vlaseva. (2018). Lactic acid beverage fortifi ed with goji berry. Bulgarian Journal of Agricultural Science, Vol. 24, No. 5, pp. 885-890.

[2] Baycheva S., Z. Zlatev, A. Dimitrova. (2016). Investigating the possibilities of document cameras for quality assessment of foodstuffs by measuring of color, International conference of virtual learning (ICVL), pp. 204-208.

[3] BNS 1111-80, 1980. Milk and milk products. Determination of acidity. (in Bulgarian).

[4] BNS 15612-83, 1983. Milk and milk products. Dairy products sensory evaluation. (in Bulgarian).

[5] Bueno L., M. Silva, P. Perina, C. Bogsan, N. Oliveira. (2014). Addition of Strawberry, Raspberry and "Pitanga" Pulps Improves the Physical Properties of Symbiotic Yoghurts. Chemical Engineering Transactions, Vol. 38, pp. 499-504.

[6] Chookietwattana K. (2014). Lactic acid production from simultaneous saccharification and fermentation of Cassava starch by Lactobacillus Plantarum MSUL 903. APCBEE Procedia, Vol. 8, pp. 156-160.

[7] Dimitrov T., G. Mihaylova, T. Iliev, N. Naydenova. (2008). Milk and Dairy Products with Methods of Research, Publishing House Stara Zagora. (in Bulgarian).

[8] IDF Standard 117B:1997. Milk and Milk Products. Yogurt - Enumeration of characteristic microorganisms - Colony-count technique at 37 degrees $C$ (Lactobacillus delbrueckii subsp. Bulgaricus and Streptococcus thermophilus) are present and viable. International Dairy Federation, Brussels, Belgium.

[9] Kent R., Doherty S. (2014). Probiotic bacteria in infant formula and follow-up formula: Microencapsulation using milk and pea proteins to improve microbiological quality. Food Research International, Vol. 64, pp. 567-576.

[10] Michael M., K. PhebusK, K. Schmidt. (2010). Impact of a plant extract on the viability of Lactobacillus delbrueckii ssp. bulgaricus and Streptococcus thermophilus in nonfat yogurt. International Dairy Journal, Vol. 20, No. 10, pp. 665-672.

[11] Qian, J., D. Liu, G. Huang. (2004). The efficiency of flavonoids in polar extracts of Lycium chinense mill fruits as free radical scavenger. Food Chemistry, Vol. 87, pp. 283288.

[12] Rotar A., C. Semeniuc, S. Apostu, R. Suharoschi, C. Mureşan, C. Modoran, C. Laslo, C. Guş, M. Culea. (2007). Researches concerning microbiological evolution of lactic acid 


\section{ARITIE

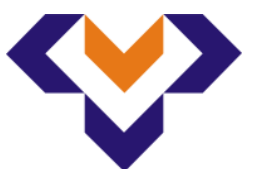 \\ Ipplied Resseirl'hes in Teednicis, Technologies and Bductition \\ Journal of the Faculty of Technics and Technologies, Trakia University https://sites.google.com/a/trakia-uni.bg/artte/}

bacteria to yoghurt storage during shelf-life. Journal of Agroalimentary Processes and Technologies, Vol. 13, No. 1, pp. 135-138.

[13] Rotar A., D. Vodnar, F. Bunghez, G. Catunescu, C. Pop, M. Jimboren, C. Semeniuc. (2015). Effect of Goji Berries and Honey on Lactic Acid Bacteria Viability and Shelf Life Stability of Yoghurt. Not Bot Horti Agrobo, Vol. 43, No. 1, pp. 196-203.

[14] Sanders M. (2003). Probiotics: considerations for human health. Nutrition Reviews, Vol. 61, No. 3, pp. 91-99.

[15] Sun-Waterhouse D., Zhou J., Wadhwa S. (2013). Drinking yoghurts with berry polyphenols added before and after fermentation, Food Control, Vol. 32, No. 2, pp. 450460.

[16] Zlatev Z., M. Petev, A. Dimitrova, V. Simeonova, S. Dinev, J. Dineva. (2015). Analysis of methods and tools for evaluation the quality of yogurt. Journal of Innovation and entrepreneurship, Year III,Vol.1-2, pp. 41-57. 